\title{
Airbrush Karawo Batik Design
}

\author{
Mursidah Waty \\ Department of Craft Engineering, Universitas Negeri Gorontalo, Indonesia \\ E-mail: mursidawaty@gmail.com
}

Received: November 14, 2018 Accepted: January 2, 2019 Published: January 3, 2019

doi: $10.5296 /$ jsss.v6i1.14159

URL: https://doi.org/10.5296/jsss.v6i1.14159

\begin{abstract}
Karawo is the name of Gorontalo's traditional embroidery widely popular since the 1600s. This present study collaborated Karawo with batik nusantara into a product along with the use of coloring method, i.e. airbrush as the finishing. Such a design is aimed at improving the quality of a local product without eliminating its local wisdom. This characteristic is to distinguish the embroidery with other similar products. The development in science, technology and arts has turned Karawo into more modern products with a fresh look. The model of Karawo is decorated by the application of the colors named 'ilabataila' consisting of red, golden yellow, green and violet. This is to represent and emphasizes the identity of the customs of Gorontalo or the local wisdom on the Karawo batik with an airbrush. The purpose of this experimental research is to identify the potential of Gorontalo that can be of use as the inspiration of new artworks and an alternative to a textile craft product. It consists of steps, such as (1) exploration of the sources of an idea from the local wisdom by observing some Karawo enterprises, visiting iconic destinations in Gorontalo and researching some literature, and (2) designing or visualizing the concepts and ideas into a drawing pattern.
\end{abstract}

Keywords: Karawo design, Batik, Airbrush

\section{Introduction}

Karawo is embroidery exclusive to Gorontalo that has been passed from generation since the 1600s. There is a need to develop this local embroidery as the local potential. However, the identity that distinguishes Karawo with other similar products, e.g. Kerawang from Tasikmalaya and Manado, must be remained. The efforts to develop Karawo are initiated by several stakeholders, such as academics and related enterprises. The term "Karawo" is derived from Gorontalo language "mokarawo" which means to cut or to create a hole. The process of embroidering Karawo demands perseverance and meticulousness of the artisans; the Karawo is, by nature, a handmade masterpiece (Rahmatia, 2015). The development in science, technology and arts has turn Karawo into more modern products with a fresh look by 
integrating the value of nusantara, such as batik and using airbrush as its finishing (Mursidah, 2017). The model of Karawo is decorated by the application of the colors named 'ilabataila' consisting of red, golden yellow, green and violet as it represents and emphasizes the identity of the customs of Gorontalo or the local wisdom on the Karawo batik with an airbrush. Such decoration is expected to produce a superior product that isreflecting the local culture of Gorontalo and to add variety and richness of the culture of nusantara.

The implementation of airbrush on Karawo batik is proposed by the previous research, i.e. the use of coloring technology of airbrush to improve the quality of textile products (Mursidah, 2016). This idea functions as the grounding in conceptualizing the design of new Karawo. The objective of the design is also to explore and promote the creativity of Karawo artisans in Gorontalo. The airbrush batik is applied on a Karawo embroidery and the cloth that retain the characteristics, i.e. the technique and the appearance, of the embroidery. Batik with airbrush coloring is similar to dyeingtechnique where it produces beautiful color gradations widely used in contemporary batik clothing. Creativity, imagination, skills in applying airbrush and insight of textile products are required to create a quality, new model of Karawo. This Karawo is expected to inspire others to improve this traditional embroidery by which it promotes the local product nation-wide and increases the economy of the artisans of Karawo.

\section{Method}

This research is experimental research on the creation of crafts (Gustami, 2004) consisting of procedures, i.e. exploration, planning, conceptualization and evaluation. The data were from observation, literature review, and documentation. The primary data of this research were collected firstlythrough observation and survey in some Karawo enterprises and boutiques. Following this step was observing some iconic sites of Gorontalo and the ornaments in the traditional house of Dulohupa, religious tourism sites, and the local libraries. This is to explore the ideas prior to designing the new Karawo. The secondary data were the information regarding the process of creating Batik and the airbrush coloring in vocational high school SMK Negeri 4, Department of Textile and automotive garages respectively. Furthermore, the data regarding the market share opportunities of the Karawo embroidery were collected. This is to identify the interest of the people in Gorontalo regarding the embroidery.

The data from the observation and interview were further analyzed accordingly. The result of this process was organized in a systematic study to ease the process of summing up. The conclusion was further analyzed and it functioned as the basics in the experiment or the creation of the Karawo batik.

\section{Results and Discussion}

\subsection{Karawo Design}

The design is a part of visual arts embedding the insight of its elements and principles. Such an insight is crucial to creating a better design. In addition, it should be noticed that design results in an artwork; this artwork is a conceptualization of the vision and feeling of the 
designer. These concepts are applied in designing karawo batik using an airbrush to conceptualize new embroidery without eliminating the essence of karawo. The designing process considers the motif and the process of creating the materials of the clothing, especially the use of chemical components or the color composition.

Karawo is among decorative fabrics with varied motifs and colors designed according to the preferences of the user or embroider. Such motifs reflect the adaptation and expression, as well as the embodiment of both modern and traditional motifs (Isnawati, 2018). Karawo, the traditional embroidery of Gorontalo, is originated from the term "Mokarawo" which means "to cut" or "to pierce" where the process of embroidering the karawo is called "kakayita" which means intertwined in the side of the piercing on the fabric. Removing the needle is permitted if the fabric is not embroidered properly. The name reflects the characteristics of the embroidery techniques where it further applied to certain fabrics and medium (Hasdiana et al., 2013). The design of the Karawo is used as the basis of the new embroidery. This process is often used in other fabrics processing the results in new materials or the development of the embroidery. Since many home enterprises produce Karawo clothing, it goes without saying that the production takes places in the non-industrial area. This enables the recycling of the design product by which it promotes the sustainability of this art industry. Optimizing such a process is among the efforts to re-create the model of the product with a fresh look.It is expected that the aforementioned efforts increase the quality and numbers of karawo embroidery.

\subsection{Batik}

The word "batik" is originally from the Malay language "dot" or small water drop. In the Javanese language, the word "batik" is rooted in the word "amba" which means "to write" and "nitik" which means "dot." The term "to write" refers to writing by using wax. Batik is an activity of drawing dots by using "canting" (special pen) with a small tip; this activity resemblances to writing dots (Sularso et al., 2009). Regardless of its literal meaning, the principle of the term "batik" is defined as a process of wax-resist dyeing applied to the whole cloth; this process is done repetitively. The wax functions to resist the dying and to create motifs or patterns on the cloth.

Batik is an ancient traditional artwork; it has been passed from generation to generation. In addition to the symbols and meanings embedded in batik, complex processes, unique and beautiful motifs and colors amaze most people (Indarmaji, 1983). This is the reason why batik is favored as its beauty represents the past and it also signifies the development of this artwork into a community industry. The art of batik has undergone a significant development represented by international market demand. It results in an increase in the production of batik. This phenomenon has been a concern for most artisans to explore batik resulting in more varied of the types and uses of batik. Such a potential serve the grounding to collaborate batik with karawo embroidery to create new and varied clothing.

\subsection{Airbush}

The history records that the first modern painting using airbrush has been found in the late 19th century. Airbrush, a technique of painting utilizing compressed air, was well-known since 1879. A tool named "distributor" was used to dye the paint on a painting media. This 
tool was invented by Abner Peeler; he dedicated his life for experimenting. Furthermore, the one who modified the tool by Peeler is Burdick. Burdick invented a more usable tool in painting employing airbrush; the shape of the tool resemblances a pen. He further got the patent for the next invention, i.e. needle control system-a system controlling the dyeing process using a needle.

In Indonesia, the airbrush technique was introduced by Dutch artisans. The artisans keep the method in secret to prevent people imitate their technique. Airbrush method is defined as a method used in a visual art utilizing compressed air in dyeing an object. Recently, this technique is widely used especially by the youths in automotive painting. This is to color their car, bike and/or helmet. A batik entrepreneur based in Yogyakarta, Hariyanto, uses a compressor if dyeing technique is used in coloring batik cloths. This results in more unique color gradations. Haryanto says that he began employing the technique for ten years; he claims "I am looking for ideas" (2010). Exploration and development of the potential and creativity have begun in the implementation of the airbrush method on karawo cloth. This is to create varied color gradations and to design contemporary motifs. Creativity, imagination, as well as the insight regarding batik using an airbrush on karawo are essential to produce quality cloths.

\subsection{Airbush Karawo and Batik Design}

The objective of designing karawo batik airbrush is to produce a new model representing a visualized identity. Such a design serve as a basis of the concept in developing karawo embroidery. Some aspects, e.g. symbols representing particular objects or verbal symbols (words) are also considered in the concept of design. This resonates to the argument by Alfian (1997) that a concept, as an abstract idea, is a mental construction that is visualized in symbols or words. A concept is made as a guideline to designing motifs of karawo embroidery in a verbal form. Furthermore, the characteristics, advantages and the lack of the karawo (comprising motif size, motif, shape, durability, color, and the technique of embroidery) are considered in designing the concept.

The result of the identification functions as the grounding of the whole concept of karawo, especially its motif. The lack of karawo motifs is due to the inability to design and draw a pattern. On top of that, the complexity of the application of motifs is determined by the results of the cut of fabric; this also serves as the basics of designing the concept. The results of the cut of the fabric and good embroidery technique are central to producing quality karawo(Mursidah, 2017). Appropriately selecting the material of the cloth, the motifs and its application must be considered to embroider an artistic karawo. Otherwise, the results of the embroidery are not of good quality. This signifies that karawo embroidery is, without question, a complex and unique process that differs this artwork with other similar embroideries (Niswatin, 2018).A demand of airbrush dyeing is increased lately as it offers a beauty gradation with an artistic touch. This later becomes the grounding in designing the motif of karawo batik with airbrush finishing exclusive to this model that differs it with other similar cloth. 


\subsection{Designing Airbrush Karawo Batik}

The designing begins by identifying the physical characteristics of the karawo and its material to ensure the quality of the embroidery. Furthermore, the outcome of the process serves as the basis for the exploration and visualization of karawobatik airbrush.

\subsection{Characteristics of Karawo Gorontalo}

Karawo as the cultural heritage holds potential as a local product that can promote the growth of the creative industry in Gorontalo. This unique embroidery demands thoroughness as the process is mostly hand-made. Each layer of fabric cloth is cut to determine the position of the motif. In other words, mistakes in this process must be avoided, especially in expensive cloth, i.e. silk cloth. The cutting process results in a tenuous fiber fabric that eases the embroidery. It is also aimed to compare horizontal and vertical fiber fabrics prior to starting embroidery the cloth with color yarns. Such characteristics of karawo are regarded as the unique artwork in Indonesia in the Nusantara Embroidery Festival at Museum Gajah, Jakarta.

Recently, there are not many people who are excel in cutting fiber fabric, especially silk fabric since it has fine and thin fibers. The material of the fiber also determines the duration of the cutting as not all fabrics are suitable for the medium of karawo. The characteristics of the karawo embroidery are provided in the following table:

Table 1. Characteristics of Karawo Embroidery

\begin{tabular}{lll}
\hline No. & Physical Traits & Characteristics \\
\hline 1 & Motif size & Varied \\
2 & Shape & Limited, the result tends to be geometric \\
3 & Motif & Animals and Plants \\
4 & Durability & Durable \\
5 & Colors & Less innovative \\
6 & Types of embroidery techniques & Ikat and Manila embroidery techniques \\
7 & Process of embroidery & Hand-made/tend to be difficult \\
\hline
\end{tabular}

(Taken from the research data, 2018).

The table above shows that the size of the motif is more varied, which is almost the size of the body, ranging from 90-125 cm as in karawo gown. Medium size motifs are on women's blouses and men's shirts ranging from $60-75 \mathrm{~cm}$ or $15-30 \mathrm{~cm}$ for small sizes. Such motifs are also often found on handkerchiefs, fans, and bags. In addition to the contemporary motives with the application of the symbols and icons in Gorontalo, minimalist style has been a trend for karawo embroidery with its own uniqueness. The motifs mostly adapt the shape of animals, such as fish, as it is regarded as the icon of Gorontalo. Other popular icons are also applied as the motifs in karawo embroidery. The variety of motifs of karawo tend to be geometric and rather stiff. This is due to the limited space in positioning the motifs and is considered as a result of the cut of fiber fabrics. Lack of accuracy in this process significantly affect the results of the 
embroidery. With that being said, the cutting should not be done continuously and at the same time. This process must be done in more than one day, and it is determined by the vision of the artisans. Otherwise, it results in poor embroidery since excessive workload may damage the artisans' sight.

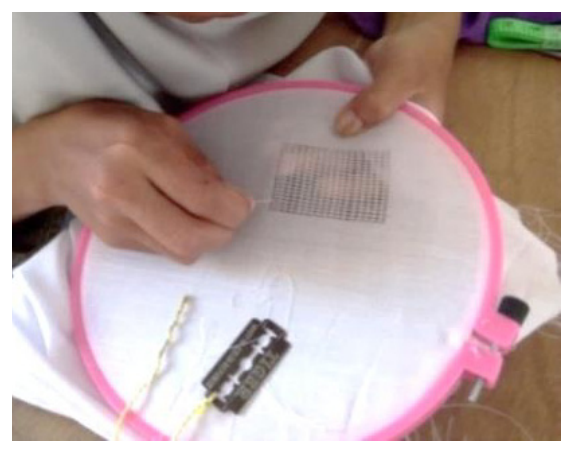

Figure 1. Fiber fabric cutting

(Taken from the research data, 2018).

The aforementioned situation seems to burden the artisans in cutting the fabric fiber by which it results in prolonging the duration of embroidery. Another issue is the fact that most of the karawo artisans are women part-timer; they do the embroidery in their free time. The process of fiber cutting is done during the day as it requires sufficient light. The materials of the fabric must also be taken into account in this process. The cutting for large motifs with the size $90-125 \mathrm{~cm}$ of fabrics takes two months. YusIryantoAbas, a designer and lecturer in UniversitasNegeriGorontalo, explains the development of the motifs of karawo embroidery based on the design. A motif is considered unique if it is favored by people as the consumer. The problem is that craftsmen are less willing to work on large-size motifs. This is due to a long work process and a lack of craftsmen, especially in the fiber cutting and production. In other words, the development of the motifs of karawo depends on the ability and willingness of the artisans. This phenomenon can result in an increase in the price of production if consumers prefer new or a large-sized motif (interview, April 2017). The complexity of the motifs and the materials of the fabric also contributes to the productivity of the artisans. The problem is also due to the limited ability of artisans to design the motifs of karawo embroidery. The artisans are lack of exploration of sources of local potential ideas; they mostly use the same concept for designing the motifs.

Most of the artisans often adopt the shape of animals and flowers as these designs are widely used. This emphasizes the needs of adapting new models of karawo embroidery by exploring sources of ideas and concepts. Icons of certain brands, and the customs and the ornaments of Gorontalo offer new alternatives tothe concept of new karawo embroidery. The strength of handmade batik products is of valuable because it is not mass produced. 


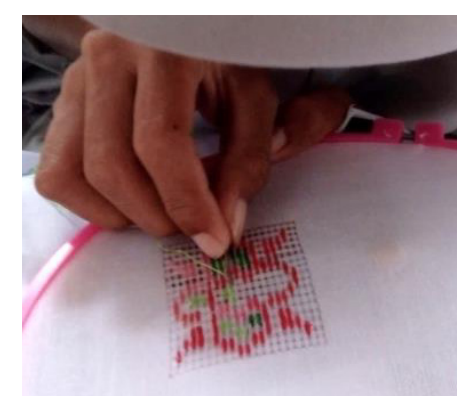

Figure 2. Karawo Embroidering

(Taken from the research data, 2018).

The complexity hindering the process of karawo embroidery is due to three factors. The first factor is the person who is responsible for designing the motifs or patterns. The second factor is the person whose job is to cut the fiber fabric as it requires certain skills . Considering the length of the pattern and the balance between the tip of the fabric fiber in embroidery is also essential. Cutting fabric fiber produces a material surface with stretched fabric fibers resembling a certain pattern. The third factor refers to the person who responsible for embroidering the cut fabric. This process employs brush and manila embroidery technique depending on the characteristics of the motifs. That complex process in karawo embroidery represents particular traits unique to this artwork.

The problems described above have resulted in the cessation of the production of the Karawo embroidery. The craftsmen have less interest in karawo embroidery due to its complexity, and it drains their energy and time. In response to this, the government and academics collaborate to promote the karawo industry to bring this artwork nation-wide. Workshops on designing motifs and techniques of karawo embroidery are among the programs initiated by the government. The effort to promote karawo embroidery started for the first time in Karawo Festival, 17-18 December 2011. This boosts the creativity of the artisans to keep designing karawo by which it draws more interest from the public as the main target of karawo cloth. As a result, the festival has been holding annually to keep promoting karawo and mediate the artisans to improve their creativity. The regional government has also endeavored to held local or national exhibition and constituting a policy to wear karawo cloth on certain occasions.

From the above discussion, it is concluded that karawo embroidery has its advantages and disadvantages. This opens a chance to fill the gap by renewing the motifs of the embroidery. It should be noted that the lack of facilities to explore the motifs and the process of fabric fiber cut may hinder the advancement of promoting karawo. Another exclusiveness of karawo embroidery is that this is a hand-made artwork with appealing motifs. To address the aforementioned issues, creativity in renewing the motifs of karawo is essential.

\subsection{Exploration of the Design of Karawo Batik Airbrush}

The initial step is preparing the visualization of the design and the approach to accomplish it. This is done by surveying, observing, studying relevant literature, and visiting karawo enterprises, boutiques, textile shops and generating other supporting data. Following this step 
is to examine the generated data. Considerations regarding the embroidery of new karawo are explored to determine the most appropriate concept to use. Such an exploration comprises the sources of ideas and its identification of the research problem, collecting data and references, and data analysis. The data analysis functions as the grounding in designing the motif. The details of the exploration step are as follow:

1) The exploration of the ideas involves observing and extracting reference sources and information to find themes. This step begins with an exploration of the possibilities of karawo embroidery functioning as a source of ideas. It aims to produce works of art that have the potential to become superior products of economically valuable regions.

2) This is also to explore the philosophical grounding reflecting the tradition and culture of Gorontalo along with its development. Field observation is done in some sites to observe the people's activity relating to the process of airbrush; this serves as the groundings in the implementation of airbrush on textile crafts.

3) Identifying ideas is done to analyze the references and the sources of information. This step begins by identifying the problem statement according to the social situation in Gorontalo and considering the references selected. This results in the formulation of research problem where the insight regarding the trend of Gorontalo people is required. Information regarding the modern tradition and culture is also needed as the sources of the idea.

4) Determining the materials is also done in the exploration process to optimize the pre-design step. Identifying the materials is done to conceptualize the artwork. The details of this step are as follow:

a. Surveying the handicraft industry and shops in Gorontalo to observe the development of the Karawo embroidery industry.

b. Identify materials based on physical properties representing the characteristic of karawo embroidery.

c. Determination of techniques, i.e. karawo embroidery and the implementation of batik with airbrush coloring, to determine the most appropriate technique in conceptualizing ideas into visual works, both in the background and structural manner.

\subsection{Designing Karawo Batik Airbrush}

This step includes determining the most appropriate techniques for realizing ideas into visual works, both in a background and a structural way. The application of the shapes and other supporting aesthetical value is to reinforce the ideas or the concepts. Following the experiment of the shapes is the manifestation and structuration of the aesthetical value reflecting on several aspects to conceptualize ideas.Some sketches of the design are provided on the following pages.

\section{Sketch Design}

Drawing some sketches based on the ideas and the results of the primary and secondary data is done firstly. These sketches are further grouped based on the process and the exploration of the visualization of the artwork. 


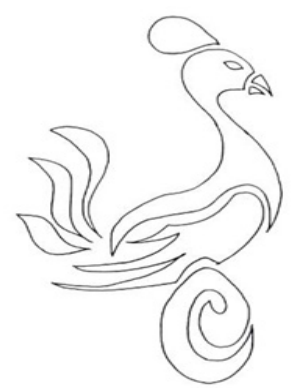

Figure 3. 'Maleo' Sketch

(Taken from research data, 2018).

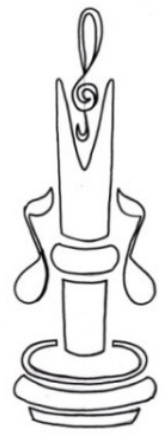

Figure 4. 'Polopalo' Sketch

(Taken from the research data, 2018).

\section{Work Design}

Following the above steps is to draw the pattern according to the characteristics of karawo embroidery. The following figures are the example of the embroidery patterns.

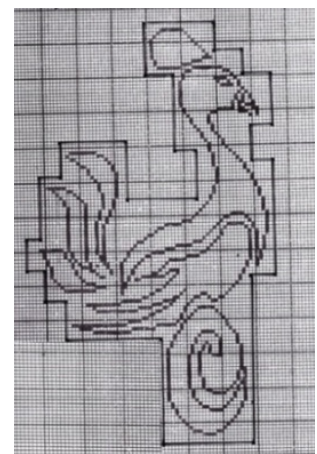

Figure 5. 'Maleo' Embroidery Pattern

(Taken from research data, 2018). 


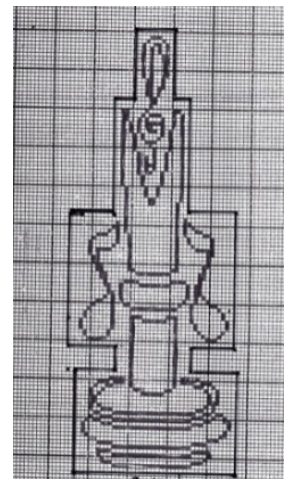

Figure 6. 'Polopalo' Embroidery Pattern

(Taken from research data, 2018).

Positioning the work pattern is done by referring to the grounding of the decoration. The application of the color is made to emphasize the color and nuance of Gorontalo culture. Its colors comprise red, yellow, green and purple. The combination of such colors reflects the value of Tilabataila or the four colors of Gorontalo (Rusli, 2000). The objective of applying the colors is to promote the local wisdom and to increase the income for karawo artisans. The final application of this process is the design of karawo batik airbrush.

\subsection{Conceptualization of Karawo Batik Airbrush}

The conceptualization of artwork cannot be done once; it undergoes several processes. This is due to the existence of several different characteristics of each technique such as the application of karawo, batik, and airbrush coloring according to the design, including its finishing. This airbrush coloring technique is a coloring art that is no stranger to the community. The application of such a coloring method is expected to attract people because it triggers creativity in an artwork expression and innovation. The process of designing karawo motifs are threefold, i.e. designing sketch, drawing pattern, and designing the decoration of the cloth .The figure below is an example of an alternative model of karawobatik airbrush with Male'o bird-shaped decoration.

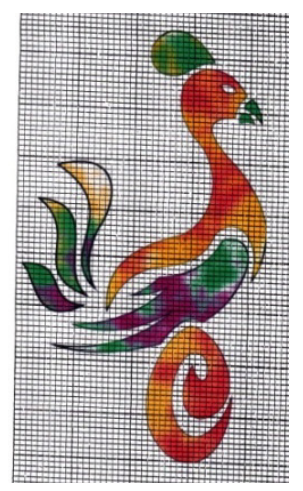

Figure 7. Male'o bird-shaped Decoration

The Implementation of Airbrush on Batik (taken from research data, 2018). 
The design of Male'o bird (side view) sketch is stylized with several variations. The crest on the bird sketch represents the characteristic of a matureMale'o bird. Stylization on the shape of the body and tail of the bird is made giving it some spaces to explore the color. In addition, such design reflects the uniqueness to the karawo batik. The technical aspect of the design is visualized on a work pattern and decoration to add the more artistic look to the embroidery. The sketch in the early exploration step functions as the basic in designing the work pattern to minimize mistakes in designing the motif on karawo embroidery. The figure below is an example of an alternative model of karawobatik airbrush with Polopalo-shaped decoration.

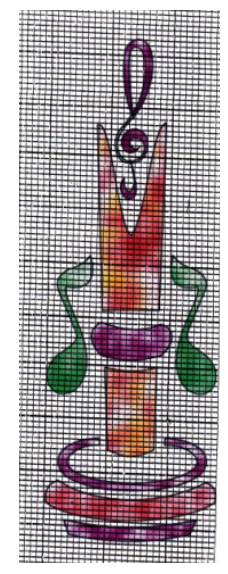

Figure 8. Polopalo-shaped Decoration

The Implementation of Airbrush on Batik (taken from research data, 2018).

The result of the visualization of the concept of design embeds the consideration of technical aspect and artistic touch that is expected to promote the variation of karawo motifs. The local wisdom of Gorontalo, such as the integration of Male'o and Polopalo motifs, is also among the aspects that should be taken into account . The combination of colors, i.e. red, dark yellow (gold), green and purple reflects the value of Tilabataila or the four colors of Gorontalo (Rusli, 2000). Each color has its meaning, such as bravery and responsibility (red), nobleness, loyalty, greatness and honesty (dark yellow or gold), fertility, wealth and peace (green), and elegance and prestige (purple). The implementation of airbrush coloring aims to add the impression of the complexity of the artwork that differs karawo with other embroideries. The application of airbrush on karawo batik results in a unique gradation of colors, making the embroidery looks more varied. It is expected that the new look adds more aesthetic value to the embroidery by which the karawo becomes a superior product.

\section{Conclusion}

The identification and analysis of characteristics result in a potential, new karawo embroidery. The strength of handmade batik products is of valuable because it is not mass produced where it is considered as the uniqueness of this new karawo embroidery. The lack of karawo motifs is due to the inability to design and draw a pattern. The ability of the artisans in cutting the fabric fiber is central to the production of karawo. In other words, the complexity of the 
application of motifs is determined by the results of the cut of fabric; this also serves as the basics of designing the concept. This later becomes the grounding in designing the motif of karawo batik with airbrush finishing exclusive to this model that differs it with other similar cloth. As a result, it is expected that this local product can compete nation-wide.

\section{References}

Alfian, T. I. (1997). Dimensi Teori dalam Wacana Ilmu Pengetahuan, in Kembang Setaman: Persembahan untuk Sang Maha Guru, Yogyakarta: BP ISI Yogyakarta.

Aesty, D. N. S. et al. (1998). Ekologi Industri [Industrial Ecology]. Direktorat Jendral Pendidikan Tinggi Departemen Pendidikan dan Kebudayaa, Jakarta.

Bank Indonesia. (2011). Survei Persepsi Masyarakat Terkait Karawo Gorontalo [Survey of Public Perception Regarding Karawo Gorontalo]. Bank Indonesia Kantor, Gorontalo.

Barnard, M. (1996). "Fashion as Communication atau Fashion sebagai Komunikasi: Cara Mengkomunikasikan Identitas Sosial, Seksual, Kelasdan Gender", translation of Idi Subandy Ibrahim \& Yosal Iriantara, Jalasutra, Yogyakarta.

Craik, J. (1994). The Face of Fashion; Cultural Studies in Fashion. Routledge, London/New York.

Gustami. (2004). "Proses Penciptaan Kriya Seni "Untaian Metodologis”. BP ISI, Yogyakarta.

Dharsono. (2015). Estetika Nusantara [The Aesthetics of Nusantara], Surakarta: ISI Press.

Hadi, R., Jumadi, D., \& Sulaiman, S. (2015). The Role of Human Capital in the Development of Sulam Karawo Creative Industry in Gorontalo. Int. J. Acad. Res., 7(1), 158-162.

Hasdiana et al, (2013). Proses Peningkatan Brand Image Kerawang Melalui Penciptaan Desain Ragam Hias Kreatif Beridentitas Kultural Budaya Gorontalo Untuk Mendukung Industri Kreatif. Gorontalo: Laporan Penelitian.

Indarmaji. (1983). Seni Kerajinan Batik, Dinas Pariwisata Daerah Istimewa Yogyakarta.

Lurie, A. (1992). The Language of Clothes Produk Fashioned. London: Bloomsbury.

Mohamad, I., Dangkua, S., Botutihe. S. N., \& Lahinta, A, (2018). Designing Contemporary Karawo Motifs for Teenagers. Journal of Arts \& Humanities, 07(08), 30-37.

Niswatin, H., Hanisa, I., \& Rahayu. (2018). The Cultural Value of Gorontalo as the Basis of Reconstruction of the Model of Organization and Finance Management of the Karawo Artisans in Indonesia. Int Conference on Community Development, 231, 470-474. https://doi.org/10.2991/amca-18.2018.131

Solomon, M. R. (1992), Consumer Behavior. Allyn and Balon. New York.

Sp. Soedarso. (2006). Trilogi Seni. Penciptaan Eksistensi dan Kegunaan Seni. ISI Yogyakarta. Yogyakarta.

Sudana, I. W. (2015). Characteristics of Karawo the Textile Ornaments from Gorontalo. 
Semarang State University, Semarang.

Sularso. (2009). 60 Tahun Gabungan Koperasi Batik Indonesia. Koperasi Pusat Gabungan Koperasi Batik Indonesia. Jakarta.

Rusli, M. (2000). Tata Krama Suku Bangsa Gorontalo. Departemen Pendidikan Nasional. Jakarta

Waty, M., \& Hasmah, H. (2016), Rekayasa Teknologi Pewarnaan Airbrush Untuk Peningkatan Kualitas Tekstil Menjadi High Fashion. MUDRA Journal Seni Budaya, 31(2).

Waty, M. (2017). Karawo Design Concept Of Airbrush Batik, Prosiding Seminar Internasional Conference on Culture, Art, and Humanities.

Waty, M. (2017). Model Desain Karawo Airbrush Batik Airbrush. Gorontalo, UNG PRESS.

\section{Copyright Disclaimer}

Copyright for this article is retained by the author(s), with first publication rights granted to the journal.

This is an open-access article distributed under the terms and conditions of the Creative Commons Attribution license (http://creativecommons.org/licenses/by/3.0/). 